\title{
An ecotoxicological analysis of the sediment quality in a European Atlantic harbor emphasizes the current limitations of the Water Framework Directive
}

\author{
Sandra F. Gonçalves, Ricardo Calado, Newton C.M. Gomes, Amadeu M.V.M. Soares, Susana Loureiro* \\ Departamento de Biologia E' CESAM, Universidade de Aveiro, 3810-193 Aveiro, Portugal
}

\section{A R T I C L E I N F O}

\section{Keywords:}

Bioassays

Elutriates

Microtox ${ }^{\circledR}$

Rotoxkit $\mathrm{M}^{\mathrm{TM}}$

Water quality

Atlantic area

\begin{abstract}
A B S T R A C T
The "PortoNovo" project was developed to standardize the methodologies for water quality management in the port areas of coastal Atlantic regions to improve the Water Frame Directive (WFD) for these specific water bodies. Under this scope, water and sediment samples were collected from five sites within the Port of Aveiro, Portugal. According to the physical and chemical parameters that were analyzed (i.e., metals, total organic carbon, polychlorinated biphenyls and polycyclic aromatic hydrocarbons), the sediments were not considered at risk based on European sediment quality laws. However, the bioassays that were performed on the sediment samples $\left(\right.$ Microtox $\left.^{\circledR}\right)$ and the standardized acute toxicity test using the marine rotifer, Brachionus plicatilis, on sediment elutriates revealed higher toxicity levels. The use of bioassays to assess sediment quality clearly complements more conservative approaches and highlights current gaps within the WFD. The approach presented here can be easily transferred to other port areas for more reliable water quality management.
\end{abstract}

() 2013 Elsevier Ltd. All rights reserved.

\section{Introduction}

Coastal port areas have a massive economic and social impact on society because marine transportation is extremely valuable for network and cargo distribution. However, environmental protection should not be disregarded, and the sustainable exploitation of these coastal areas must be clearly considered. Port pollution is, indeed, a concern that has been and remains under discussion and evaluation. These discussions focus on the main activities and sources that are responsible for pollution, policies and recommendations (Goulielmos, 2000; Bailey and Solomon, 2004; Darbra et al., 2009). Currently, there is an urgent need to improve environmental data monitoring techniques because the implementation of continuous monitoring programs is crucial for understanding the environmental impacts of port activities (Darbra et al., 2009). Ports are bordered by huge water bodies, such as oceans, rivers and estuaries, and the water quality of these areas is one of the main environmental concerns for their sustainable operation.

According to the European Water Framework Directive (WFD) (Council Directive 2000/60/EC), these water bodies are classified as heavily modified water bodies (HMWB) because they continuously suffer from severe physical and chemical modifications due to anthropogenic activities. The directive establishes a framework

\footnotetext{
* Corresponding author. Tel.: +351 234370779; fax: +351234372587.

E-mail addresses: sgoncalves@ua.pt (S.F. Gonçalves), rjcalado@ua.pt (R. Calado), gomesncm@ua.pt (N.C.M. Gomes), asoares@ua.pt (A.M.V.M. Soares), sloureiro@ ua.pt (S. Loureiro).
}

for the protection of surficial and ground waters. Its main objective is to achieve a 'good ecological status' for all European water bodies until 2015 (Council Directive 2000/60/EC; Borja et al., 2006), with the exception of HMWB, where the ecological status assessment is based on achieving a 'good ecological potential' (Council Directive 2000/60/EC; Borja and Elliott, 2007).

One of the issues that deserves special attention in evaluating the water quality of aquatic systems is the interaction of heavy metals and other potential hazards with the sediment (DelValls et al., 1998). The sediment is a depository compartment that can absorb and release contaminants and influence the overlying water and its quality (Valdés et al., 2005; Alagarsamy, 2006). In addition, there are several organisms that inhabit this compartment, play an important role in environmental processes and may display social and/or economic value. These organisms can be negatively affected by the interactions between the sediment and the water column (Quintino et al., 1995). The accumulation, distribution and increase in contamination in sediments are predominantly influenced by anthropogenic activities (Huang and Lin, 2003; Chen et al., 2007). Port areas are rich in industrial and naval activities, and several contaminants, such as metals, PCBs and PAHs, are known to be present in ports worldwide (Birch and Taylor, 1999; Chen et al., 2007; Jones et al., 2005; Morillo et al., 2004). In fact, high concentrations of PAHs in the environment are mainly a consequence of anthropogenic sources, such as industrial and domestic wastes or petroleum handling (Boonyatumanond et al., 2006; Soclo et al., 2000). Metals are also continuously introduced in industrialized coastal and estuarine regions through anthropogenic actions (Zhang et al., 2007). 
Therefore, port areas are excellent locations to monitor these human impacts on the environment (Fatoki and Mathabatha, 2001).

This research was developed under the scope of the European project PortoNovo - "Water Quality in Harbors", the goal of which is to standardize the methodologies used to manage water quality in port areas of the north-eastern Atlantic and to help improve and implement the WFD for these specific water bodies (HMWB). The PortoNovo project involved different universities and institutions, as well as the collaboration of ports from six European countries: Portugal, Spain, France, Ireland and the United Kingdom. Previous studies have also addressed the development of methodologies to evaluate risk assessment in harbors in an attempt to achieve sustainable development of these areas, including the following two projects. (1) The Ecoport project, "Towards A Sustainable Transport Network", was developed by the Valencia Port Authority and conducted at the Valencia Port (Peris-Mora et al., 2005) with the objective of designing a system of sustainable management indicators for further application in other ports in Spain and Europe. Port activities were analyzed, and seventeen environmental indicators and their potential environmental impacts were identified (e.g., inner port water quality, which considers spills or leaks from the transfer of oil products and bulk liquids from vessel to lorry). (2) The Pearl project's ("Port Environmental Information Collector") main results were described in an investigation by Darbra et al. (2009), based on data collected from 26 European ports, to underscore the importance of environmental monitoring and support the development of a port environmental management system. Thus, so far, an ecotoxicological approach has not been considered when evaluating the water and sediment quality that results from environmental management activities in areas under port jurisdiction. Nonetheless, there are several studies addressing the environmental status of marine/estuarine environments based on ecotoxicological bioassays that clearly indicate the relevance of this type of approach (Costa et al., 1998; Nendza, 2002; Narracci et al., 2009).

Within the PortoNovo project and with the goal of implementing an ecotoxicological approach to evaluate water and sediment quality in ports, a collaboration was initiated with the port of Aveiro to improve the WFD for these specific water bodies (HMWB). A biomonitoring campaign was formed in August 2010 to establish and implement reproducible and standardized bioassays to determine the environmental quality status of areas under port jurisdiction, with possible applications for the WFD. To achieve this goal, two standardized bioassays were used: the Microtox ${ }^{\circledR}$ bioassay,

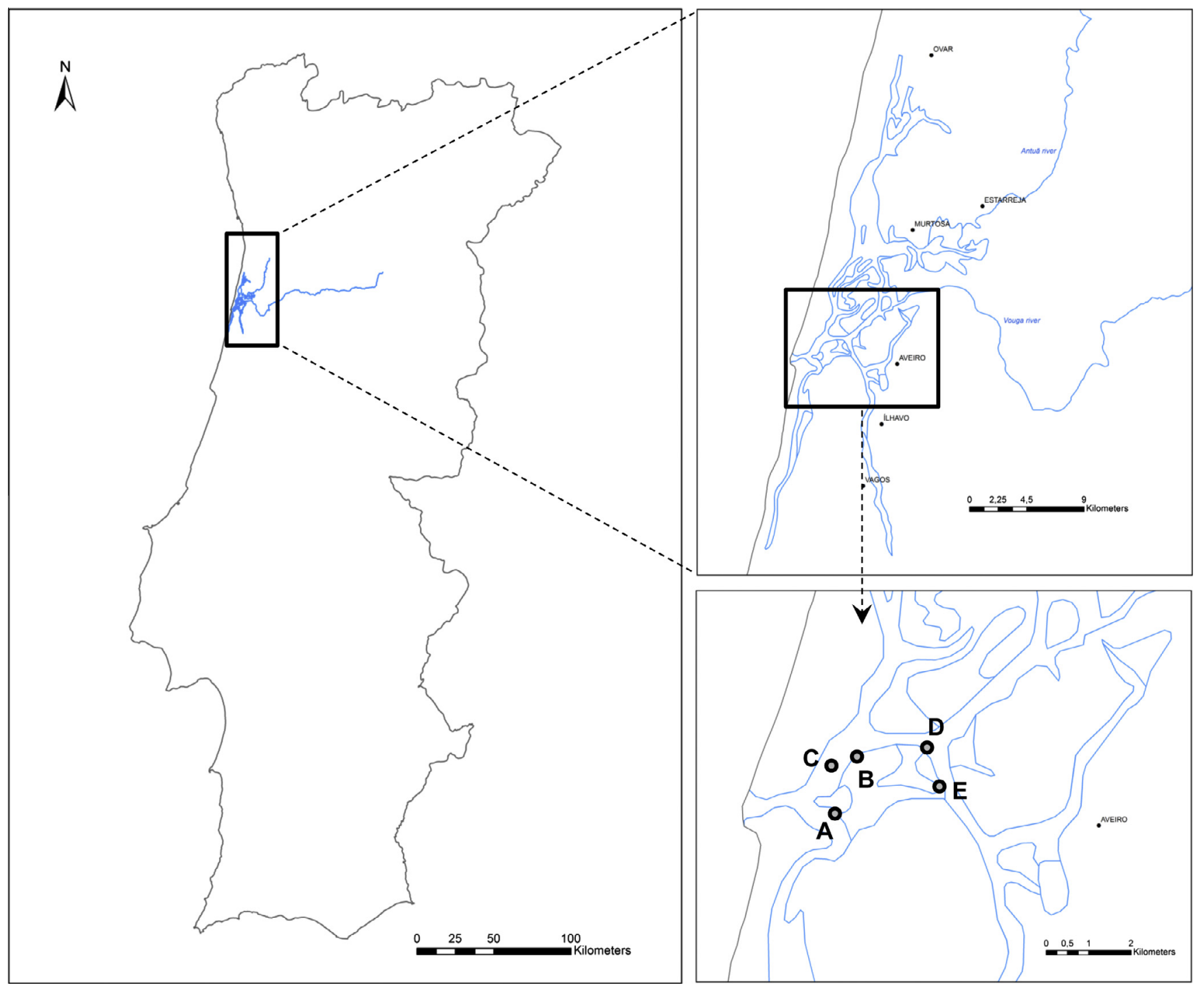

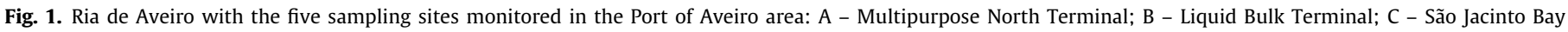
(reference site); D - Liquid Bulk Terminal; E - Distant Fisheries Port. 
which was performed on sediment samples using the marine luminescent bacteria Vibrio fischeri, and the standardized 24-h acute toxicity test performed on sediment elutriates, using the marine rotifer Brachionus plicatilis.

\section{Materials and methods}

\subsection{Sampling sites}

The Port of Aveiro is located in northwest Portugal $\left(40^{\circ} 39^{\prime} 28.87^{\prime \prime} \mathrm{N}, 8^{\circ} 43^{\prime} 03.94^{\prime \prime} \mathrm{W}\right)$ within a multi-branched and shallow estuarine system, the Ria de Aveiro coastal lagoon. Two main rivers drain into this estuarine system: the Antuã and the Vouga Rivers (Fig. 1). The port is located near the only artificial inlet to the Ria de Aveiro and is considered a multifunctional port. It plays a key role in serving various industrial sectors and is considered the largest infrastructure handling conventional general cargo port in the central region of mainland Portugal (http://www.portodeaveiro.pt).

Water and sediment samples were collected from five sites within the jurisdictional area of the Port of Aveiro during the summer of 2010: A - the Multipurpose North Terminal $\left(40^{\circ} 38^{\prime} .741 \mathrm{~N}\right.$, $\left.8^{\circ} 43^{\prime} .549 \mathrm{~W}\right) ; \mathrm{B}$ - the Liquid Bulk Terminal $\left(40^{\circ} 39^{\prime} .164 \mathrm{~N}\right.$, $8^{\circ} 43^{\prime} .358 \mathrm{~W}$ ); C - the São Jacinto Bay, which was chosen as the reference site $\left(40^{\circ} 39^{\prime} .287 \mathrm{~N}, 8^{\circ} 43.906 \mathrm{~W}\right)$; D - the Liquid Bulk Terminal, located next to the docking site $\left(40^{\circ} 39^{\prime} .499 \mathrm{~N}, 8^{\circ} 42^{\prime} .484 \mathrm{~W}\right)$ and $\mathrm{E}$ - the Distant Fisheries Port $\left(40^{\circ} 38^{\prime} .858 \mathrm{~N}, 8^{\circ} 41^{\prime} .891 \mathrm{~W}\right)$. One water sample and four sediment samples were collected from each site. The sediment samples were collected using corers by professional SCUBA divers and were divided into subsamples according to depth, i.e., 5,10 and $30 \mathrm{~cm}$. Water samples were stored in darkness at $4{ }^{\circ} \mathrm{C}$ and sediment samples at $-20^{\circ} \mathrm{C}$ until further analysis.

\subsection{Elutriate extraction and B. plicatilis acute tests}

The elutriates were prepared by adding artificial seawater at a salinity of 35, which was produced by mixing ultrapure water with marine salt (PRODAC International) and sediment samples at a ratio of $1: 2$, sediment:water (wet weight). The elutriates were then shaken in 100-mL Erlenmeyer flasks in a benchtop orbital shaker for $24 \mathrm{~h}$ in darkness at $20^{\circ} \mathrm{C}$ (Loureiro et al., 2005). After resting for $30 \mathrm{~min}$, the supernatant was centrifuged for $30 \mathrm{~min}\left(4^{\circ} \mathrm{C}\right)$ at $4000 \mathrm{~g}$. The supernatant was then collected and stored at $4{ }^{\circ} \mathrm{C}$ for no longer than 1 week. The elutriates were used in the $B$. plicatilis acute tests. The euryhaline rotifer $B$. plicatilis was used to perform the standardized 24-h acute toxicity test via the rotifer toxicity test-kit Rotoxkit M $\mathrm{M}^{\mathrm{TM}}$ (MicroBioTests Inc., Nazareth, Belgium). Rotifers were obtained by hatching cysts at $25^{\circ} \mathrm{C}$ under continuous illumination in artificial seawater at a salinity of 20 , prepared as described above. After approximately $28 \mathrm{~h}$, the cysts hatched, and rotifers were transferred to artificial seawater at a salinity of 35 for $1 \mathrm{~h}$ to adapt to the salinity shift. The tests were held in Multiwell ${ }^{\circledR}$ plates with six replicates per sediment elutriate and five rotifers each, plus a control replicate with only salt water. They were incubated at $25{ }^{\circ} \mathrm{C}$ in darkness for $24 \mathrm{~h}$. During the test, there was no medium renewal or feeding. The number of dead rotifers was then counted in each well, and the mean values for rotifer mortality were calculated.

\subsection{Microtox ${ }^{\circledR}$ bioassay}

The marine luminescent bacteria $V$. fischeri was used in the Microtox ${ }^{\circledR}$ bioassays. A 1:2 (sediment:water) dilution was made using the diluent from the Microtox ${ }^{\circledR}$ kit, and elutriates of all of the sediment samples/depths were analyzed with the basic solidphase test (Basic SPT) following the protocols described by Azur Environmental (Azur, 1998). A series of dilutions were carried out in this bioassay after the dilution of sediment samples with the Microtox diluent and the bacterial luminescence was measured after 15 min of exposure using the Microtox M500 Toxicity Analyzer. The $50 \%$ reduction in luminescence was measured using the Microtox Data Collection and Reduction Software (Microbics) and reported in mg sediment/L. Values were then transformed into percentage.

\subsection{Physical-chemical analysis}

For each sampling site, the $\mathrm{pH}$ (WTW pH 330/SET-2), dissolved oxygen (WTW OXI 330/SET), temperature (WTW OXI 330/SET), electrical conductivity (WTW Cond 330i/SET) and salinity (WTW Cond 330i/SET) of the seawater were measured in situ. The HACH KIT DR/2000 Spectrophotometer was used in the laboratory to measure nitrites (Method 8507), nitrates (Method 8171), ammonia (Method 8038) and phosphate (Method 8048) in the water samples.

For sediment analysis, pooled samples were prepared for each sampling site/depth combination. The percentage of total organic carbon (TOC) was measured in the sediment samples from each site, after lyophilization, using an IRMS (Thermo Electron Corporation) with a Delta V advantage mass detector, following the "Soil quality" protocol of the British Standard 7755-3.8 (BS, 1995) and the ISO 10694 (ISO, 1995) protocol. The conversion of organic samples into simple gases was completed in an elemental analyzer that was coupled to a GC-Box before using the mass spectrometer. The $\mathrm{K}$ factor was determined using an Acetanilide standard (Thermo Electron), and a linear relationship was employed to calculate the unknown \% of carbon in the sample. The metal contents were measured in the sediment samples with ICP-OES for Al, according to protocol ISO 11885 (ISO, 2007), and with ICP-MS for the remaining metals, according to protocol ISO 17294 (ISO, 2005). The elutriate samples were run through ICP-OES for $\mathrm{Al}, \mathrm{Cu}, \mathrm{Cr}$, $\mathrm{Ni}$ and $\mathrm{Zn}$, according to protocol ISO 11885 (ISO, 2007), and ICP-MS for the remaining metals, according to protocol ISO 17294 (ISO, 2005). Polychlorinated biphenyls (PCBs) and polycyclic aromatic hydrocarbons (PAHs) were also measured, but only in the sediment samples, according to the following protocols: DIN 38407 part 2 (DIN, 1993) and EPA 8082 (USEPA, 1996a) for PCBs; EPA 8270 (USEPA, 1996b), EPA 8131 (USEPA, 1996c), EPA 8091 (USEPA, 1996d) and CSN EN ISO 6468 (ISO, 1998) for PAHs.

\subsection{Data analysis}

For the B. plicatilis acute tests, a two-way analysis of variance (ANOVA) was performed to analyze the effect of both main factors, the sampling site and depth. The ANOVA was followed by Tukey's honestly significant difference multiple-comparison test to compare all five sites within the three depths selected (Zar, 1996). The violations of normality and homoscedasticy were checked using Shapiro-Wilk's and Barlett's tests, respectively. The ANOVA tests were performed using the software Statistica 7.0 for Windows (StatSoft, Aurora, CO, USA).

For the Microtox ${ }^{\circledR}$ basic solid-phase test bioassay, the effective concentration inducing 50\% effect (EC50 $15 \mathrm{~min}$ ) was calculated using the Microtox Data Collection and Reduction Software (Microbics) and reported in mg sediment/L (Azur, 1998). The EC50 was then calculated as the percentage of sediment able to induce a reduction of $50 \%$ of bacterial luminescence. 


\section{Results}

\subsection{Physical-chemical}

The physical and chemical parameters of the water samples that were measured at each site are summarized in Table 1. Similar values of electrical conductivity (EC), salinity, nitrite $\left(\mathrm{NO}_{2}^{-}\right)$and phosphate $\left(\mathrm{PO}_{4}^{3-}\right)$ were recorded at all five sampling sites. The TOC ranged between $0.28 \%$ and $4.36 \%$, with sampling site $C$, the reference site, having the lowest values and sampling site $\mathrm{E}$ the highest (Table 2). Table 3 lists the metal concentrations that were measured in the sediment and elutriate samples for all of the sampling sites, which were collected at three different sediment depths. The highest concentrations in the sediment samples were of aluminum and zinc, ranging between $4.24 \times 10^{4}$ and $8.31 \times 10^{4} \mu \mathrm{g} / \mathrm{g}$, and 28.1 and $199.4 \mu \mathrm{g} / \mathrm{g}$, respectively, with the reference site $(C)$ having the lowest values. Slightly lower concentrations of chromium and lead followed, ranging between 13.8 and $56.5 \mu \mathrm{g} / \mathrm{g}$ and 19.1 and $45.5 \mu \mathrm{g} / \mathrm{g}$, respectively, where the lowest values were also recorded in the reference site (C). High concentrations of aluminum were also detected in the elutriate samples, ranging from 65 to $308 \mu \mathrm{g} / \mathrm{L}$. The PCBs analysis resulted in values below the limits of detection. Conversely, PAHs were detected above the detection limits for site A ( $5 \mathrm{~cm}$ depth), where the concentration of naphthalene (Naph) was $0.017 \mu \mathrm{g} / \mathrm{g}$, phenanthrene (Phe) was $0.018 \mu \mathrm{g} / \mathrm{g}$, fluoranthene (Fluo) was $0.026 \mu \mathrm{g} / \mathrm{g}$, benzo(a)anthracene (BaA) was $0.012 \mu \mathrm{g} / \mathrm{g}$, chrysene (Chry) was $0.014 \mu \mathrm{g} / \mathrm{g}$, benzo(k)fluoranthene (BkF) was $0.011 \mu \mathrm{g} / \mathrm{g}$, and for site $\mathrm{B}$ (10 cm depth), the concentration of Phe was $0.022 \mu \mathrm{g} / \mathrm{g}$ and Fluo of was $0.026 \mu \mathrm{g} / \mathrm{g}$ (sediment dry weight).

\subsection{Ecotoxicological assays}

The 24-h acute toxicity tests that were performed with the marine rotifer $B$. plicatilis were considered valid according to the acceptability criteria established in the Rotoxkit $\mathrm{M}^{\mathrm{TM}}$, i.e., mortality did not exceed $10 \%$ in the control treatments. The lowest mortality was recorded for the reference site (C), with mean values of less than $10 \%$ in all sediment samples, regardless of depth (Fig. 2). At sampling site E, the mean values increased with depth, though they remained approximately $10 \%$. The highest mortality was observed at sampling site $A$ in the sediment sample that was collected at a depth of $5 \mathrm{~cm}$; the mean value was above $20 \%$ and decreased at higher depths. At sampling site D, the recorded mortality was similar among the three different depths, approximately $15 \%$. At sampling site B, the mean values for mortality varied between $10 \%$ and $15 \%$. The two-way ANOVA performed to test the effects of sampling site and depth indicated that depth did not significantly affect the mortality of $B$. plicatilis $(p=0.54)$ and that there was no significant interaction between the two factors $(p=0.35)$. However, mortality was significantly influenced by the sampling site $(p<0.05)$. Tukey's test revealed that the mortality that was obtained for the reference site $(C)$ was significantly lower than that recorded for sampling sites A $(p=0.01)$ and D $(p=0.04)$ (Fig. 2).
Table 2

Total organic carbon (TOC) measured in the sediment pool samples for all five sampling sites (A - Multipurpose North Terminal; B - Liquid Bulk Terminal; C - São Jacinto Bay - reference site; D - Liquid Bulk Terminal; E - Distant Fisheries Port), collected at three different depths $(5,10$ and $30 \mathrm{~cm})$.

\begin{tabular}{llllll}
\hline TOC\% & \multicolumn{5}{l}{ Sampling sites } \\
\cline { 2 - 6 } & A & B & C & D & E \\
\hline Depth $(\mathrm{cm})$ & & & & & \\
5 & 2.51 & 1.45 & 0.29 & 1.26 & 3.25 \\
10 & 2.72 & 2.37 & 0.28 & 2.89 & 4.36 \\
30 & 2.49 & 3.03 & 0.58 & 2.37 & 1.53 \\
\hline
\end{tabular}

With the exception of the reference site (C), the sampling sites had high toxicity in the basic solid-phase test Microtox ${ }^{\circledR}$ at each of the three different depths of sediment sampled. The presence of low percentages of sediment samples caused $50 \%$ inhibition in Vibrio fisheri luminescence (EC50 $15 \mathrm{~min}$ ), ranging through a tight scale between $4.05 \%$ and $19.46 \%$ (Fig. 3 ).

\section{Discussion}

Coastal areas are densely occupied by numerous industries related to fisheries, aquaculture, naval and petrochemical activities, among others, and commonly receive both industrial and domestic wastewater discharges. To make a proper evaluation of the state of contamination of the Port of Aveiro, both water samples and predominantly sediment samples were analyzed because the surrounding sediments are known to have a major impact on water quality (Riba et al., 2004). Water samples can be considered static samples that only provide information for a specific and restricted period of time, i.e., a "snapshot", while sediment samples can provide information over a longer temporal scale (Fatoki and Mathabatha, 2001) because they can act as sinks for pollutants in aquatic (eco)systems (Liß and Ahlf, 1997).

In Portugal, the national legislation, transcribed from the EU legislation, (Portaria n`1450/2007 de 12 de Novembro de 2007, Diário da República) from the Ministry of Environment, Spatial Planning and Regional Development, establishes the regime for the use of water resources and states the Sediment Quality Criteria for dredged materials. This legislation establishes five categorical levels, which classify materials/sediments according to their degree of chemical contamination (Table 4 and Supplementary data, Table S1) and states that the contaminants to be analyzed in sediments are mostly metals, PCBs and PAHs. According to this categorical system, the sediments that were collected within the Port of Aveiro's jurisdiction area are ranked between levels 1 or 2, due to their metal content. PCBs and PAHs concentrations are within the limits stipulated for level 1 at all five sampling sites. The reference site of our study (site C), is considered a level 1 sediment (i.e., clean dredge material), while sediments from all of the other sampling sites fall into level 2 (i.e., dredged material with trace levels of contaminants). Thus, after dredging, the choice of the disposal site must also be based on the background levels of contamination at the destination site.

\section{Table 1}

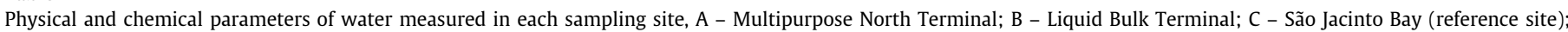

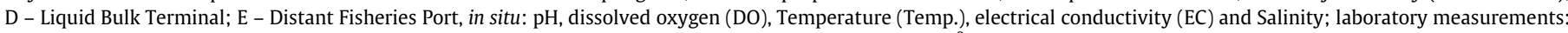
suspended solids (SS), nitrite $\left(\mathrm{NO}_{2}^{-}\right)$, nitrate $\left(\mathrm{NO}_{3}^{-}\right)$, ammonia $\left(\mathrm{NH}_{3}\right)$, ammonium $\left(\mathrm{NH}_{4}^{+}\right)$and phosphate $\left(\mathrm{PO}_{4}^{3-}\right)$.

\begin{tabular}{|c|c|c|c|c|c|c|c|c|c|c|c|}
\hline Sampling sites & $\mathrm{pH}$ & $\mathrm{DO}(\mathrm{mg} / \mathrm{L})$ & Temp. $\left({ }^{\circ} \mathrm{C}\right)$ & $\mathrm{EC}(\mathrm{ms} / \mathrm{cm})$ & Salinity $(\% \circ)$ & $\mathrm{SS}(\mathrm{mg} / \mathrm{L})$ & $\mathrm{NO}_{2}^{-} \mathrm{mg} / \mathrm{L}$ & $\mathrm{NO}_{3}^{-}(\mathrm{mg} / \mathrm{L})$ & $\mathrm{NH}^{3}-\mathrm{N}(\mathrm{mg} / \mathrm{L})$ & $\mathrm{NH}^{4}(\mathrm{mg} / \mathrm{L})$ & $\mathrm{PO}_{4}^{3-}(\mathrm{mg} / \mathrm{L})$ \\
\hline A & 7.97 & 7.82 & 19.7 & 48.8 & 35.6 & 18.2 & 0.01 & 3.08 & 3.36 & 3.55 & 0.03 \\
\hline B & 8.00 & 9.13 & 18.0 & 48.7 & 35.6 & 16.8 & 0.00 & 2.20 & 3.36 & 3.55 & 0.07 \\
\hline C & 8.02 & 9.13 & 16.9 & 48.7 & 35.6 & 25.6 & 0.003 & 2.20 & 3.36 & 3.55 & 0.02 \\
\hline D & 7.86 & 7.30 & 19.4 & 48.0 & 35.3 & 30.4 & 0.01 & 2.64 & 3.36 & 3.55 & 0.02 \\
\hline $\mathrm{E}$ & 7.82 & 7.07 & 20.2 & 49.0 & 35.8 & 31.2 & 0.00 & 2.64 & 3.36 & 3.55 & 0.03 \\
\hline
\end{tabular}




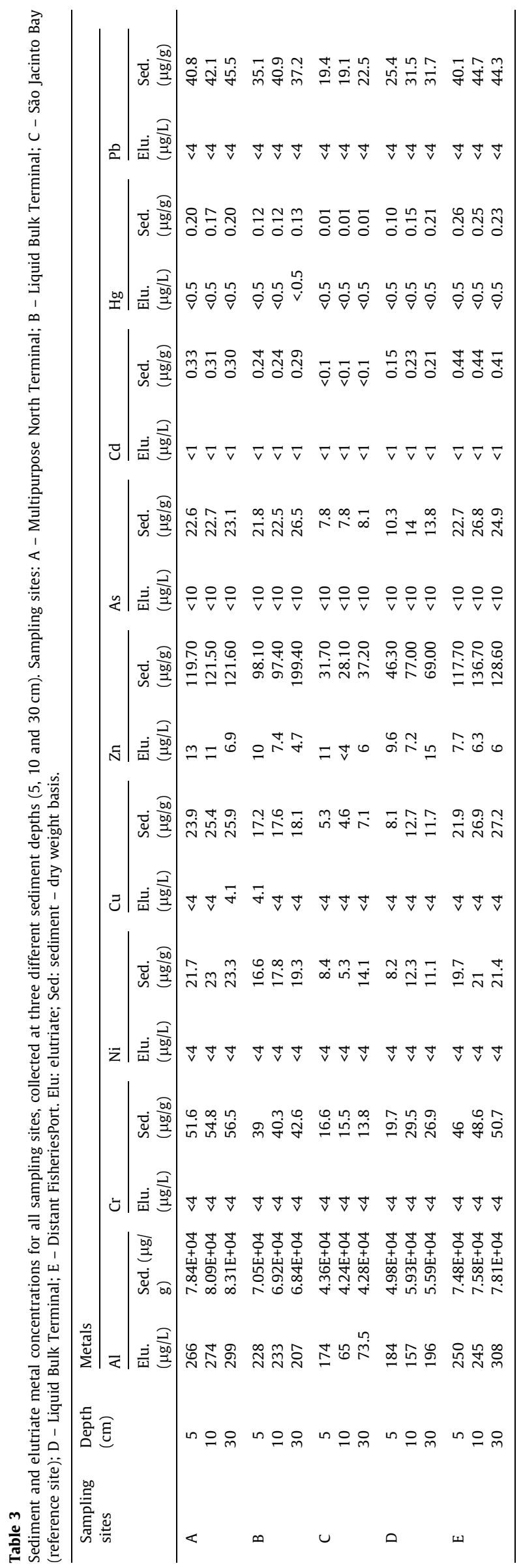

Sampling site D falls into this level as a consequence of the concentration of lead that was recorded in our study, which exceeds the value stipulated for level 1 . In all of the other cases, several metals are above the values stipulated for level 1, pushing those sediments into level 2 . When comparing the metal concentrations of the Port of Aveiro with ports in other coastal areas, namely those located on the southwest coast of Spain (Morillo et al., 2004), where high concentrations of various metals were recorded $(649 \mu \mathrm{g} / \mathrm{g} \mathrm{Zn}, 336 \mu \mathrm{g} / \mathrm{g} \mathrm{Cu}, 197 \mu \mathrm{g} / \mathrm{g} \mathrm{Pb})$, and Kaohsiung Harbour in Taiwan (up to $470 \mu \mathrm{g} / \mathrm{g}$ for $\mathrm{Pb}, 900 \mu \mathrm{g} / \mathrm{g}$ for $\mathrm{Cr}$ and $1369 \mu \mathrm{g} / \mathrm{g}$ for $\mathrm{Zn}$ ) (Chen et al., 2007), our study location is, in general, less contaminated. The sediment metal analysis performed in this study highlights the importance of making a vertical survey along the sediment depth gradient to properly evaluate the sediment quality instead of a simple horizontal analysis. The presence of bivalves at different depths of the sediment samples indicates that animals can move to at least a depth of $30 \mathrm{~cm}$ in the sediment and reinforces the relevance of performing a vertical survey to properly monitor the potential impacts on local fauna. Considering the chemical evaluation of our sediment samples, the substantial increase in $\mathrm{Zn}$ concentration with depth $(5 \mathrm{~cm}-98.10 \mu \mathrm{g} / \mathrm{g} ; 30 \mathrm{~cm}-199.40 \mu \mathrm{g} / \mathrm{g})$ at sampling site B reinforces the relevance of studying deeper sediment layers. This aspect has already been highlighted by previous studies (Liu et al., 2003; Zhou et al., 2004; Adamo et al., 2005), given that metals have the ability to move along sediments to deeper layers. PCBs are commonly detected in marine sediments, and PAHs are also known to persist in this matrix due to their hydrophobicity (Sprovieri et al., 2007). Nonetheless, the majority of the analyses performed in this study revealed PCB and PAH levels below the detection limits, with the exception of some PAHs at sampling sites A and B. These results are certainly related to the anthropogenic sources that are present in the study area, although all of the sites can be considered to have low levels of contamination. Previous studies surveying harbors elsewhere revealed much higher levels of PAHs, ranging from 1.16 to $3.38 \mu \mathrm{g} / \mathrm{g}$ in the Hsin-ta Harbour, Taiwan (Fang et al., 2003) and 0.62 to $1.69 \mu \mathrm{g} / \mathrm{g}$ in Poole Harbour, England (Woodhead et al., 1999).

The categorical system for dredge material in other European countries is somehow different from the legally valid system in Portugal. In Spain, there are three different categorical levels for materials/sediments according to their degree of chemical contamination (CEDEX, 1994), while there are only 2 in France (Arrêté du 14/06/00) and the UK (OSPAR, 2004) (Table 4). Another major difference between the Portuguese legislation and those from other European countries is the lack of reference to any type of bioassays for evaluating sediment toxicity. In Spain, bioassays are still under debate, but the following tests have been suggested: Microtox ${ }^{\circledR}$, acute toxicity tests with amphipods, the polychaete Arenicola, bivalves and the sea-urchin Echinocardium, as well as liquid phase tests, the acute toxicity test with rotifers or the equinoderms' fertilization test (CEDEX, 1994). In France, this approach is already followed; further, to assess the ecological risk of dredged harbor sediments, the software program GEODRISK was developed, which considers the reference quality levels of contaminants in sediments (Alzieu and Quiniou, 2002). This software is able to discriminate dredged sediments according to their contamination level, potential and measured toxicity. For this assessment, several toxicity tests were selected based on their sensitivity and ability to distinguish several types of contamination, namely the solid phase Microtox $^{\circledR}$ test, which is one of the bioassays under consideration in Spain and was also employed in the present study. The Microtox ${ }^{\circledR}$ test is versatile, quick and low cost, making it a financially acceptable and advantageous option as a first screening approach (Girotti et al., 2008). 


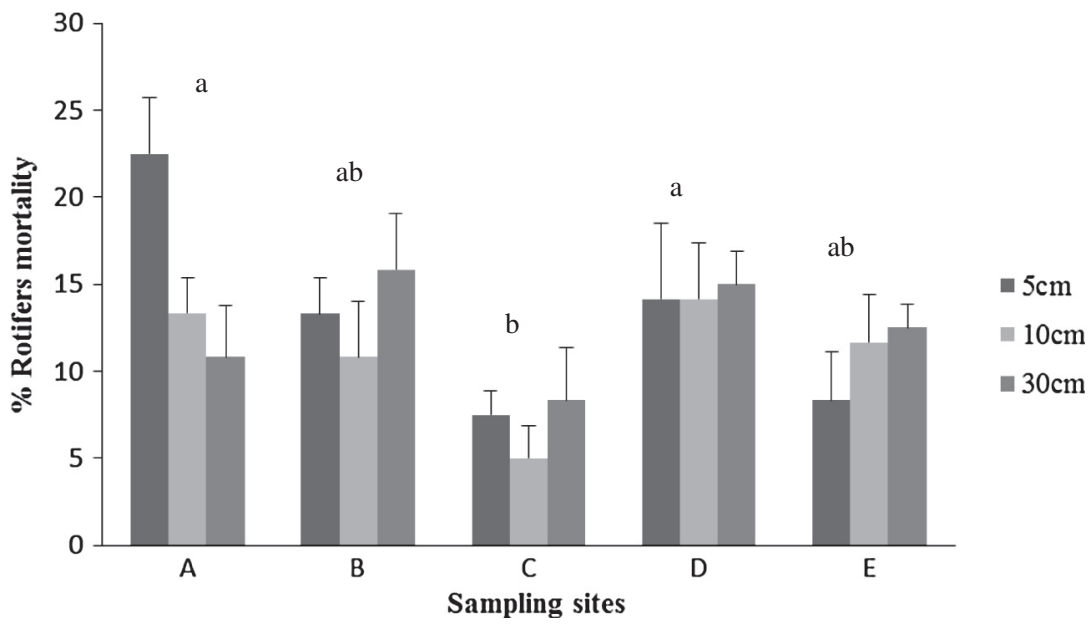

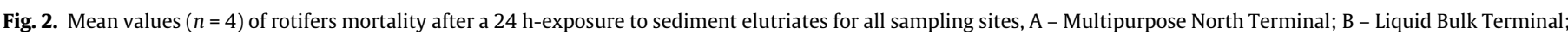

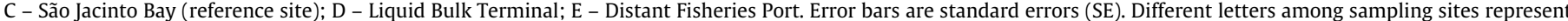
significant differences at $p<0.05$.

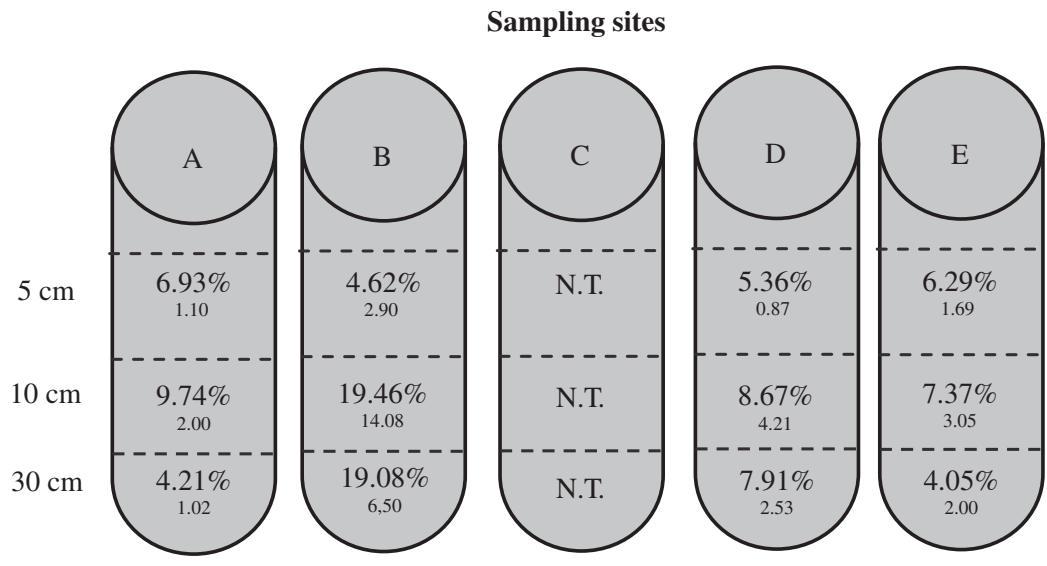

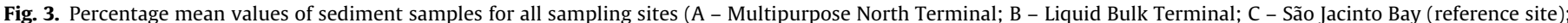

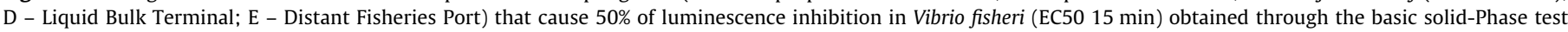
Microtox, with standard error values below. N.T. - not toxic.

\section{Table 4}

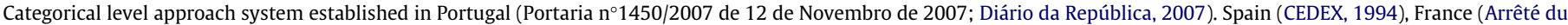
14/06/00) and UK (OSPAR Guidelines, 2004).

\begin{tabular}{|c|c|c|c|c|c|}
\hline Level & 1 & 2 & 3 & 4 & 5 \\
\hline Portugal & $\begin{array}{l}\text { Clean dredged material that } \\
\text { can be dumped at sea or } \\
\text { replaced in places subject to } \\
\text { erosion or used to feed } \\
\text { beaches without } \\
\text { restrictions }\end{array}$ & $\begin{array}{l}\text { Dredged material with traced } \\
\text { amount of contaminants and } \\
\text { dumped is allowed taking } \\
\text { into account the } \\
\text { characteristics of the } \\
\text { dumping site }\end{array}$ & $\begin{array}{l}\text { Dredged material slightly } \\
\text { contaminated that when } \\
\text { dumped a study is needed at } \\
\text { the site of dumping and } \\
\text { monitoring programs are } \\
\text { necessary }\end{array}$ & $\begin{array}{l}\text { Contaminated dredged } \\
\text { material that can be } \\
\text { Disposed on land, } \\
\text { with subsequent } \\
\text { coverage in } \\
\text { impervious soil }\end{array}$ & $\begin{array}{l}\text { Highly contaminated dredged } \\
\text { materials that ideally should not be } \\
\text { dredged; dredged material should } \\
\text { be previously treated or disposed in } \\
\text { authorizes landfill and dumping is } \\
\text { forbidden }\end{array}$ \\
\hline Spain & $\begin{array}{l}\text { Dredged material can be } \\
\text { dumped at sea after the } \\
\text { characterization of } \\
\text { mechanical effects }\end{array}$ & $\begin{array}{l}\text { Dredged material with } \\
\text { moderate concentration of } \\
\text { contaminants that can only } \\
\text { be dumped at sea according } \\
\text { to specific } \\
\text { recommendations }\end{array}$ & $\begin{array}{l}\text { Dredged material with high } \\
\text { concentrations of } \\
\text { contaminants that should be } \\
\text { isolated from marine waters } \\
\text { and subjected to appropriate } \\
\text { treatment }\end{array}$ & - & - \\
\hline France & $\begin{array}{l}\text { Level below which immersion } \\
\text { can be authorized without } \\
\text { specific study }\end{array}$ & $\begin{array}{l}\text { Level above which immersion } \\
\text { is forbidden if not proven to } \\
\text { be the solution less harmful } \\
\text { to the environment }\end{array}$ & - & - & - \\
\hline UK & $\begin{array}{l}\text { Contaminant levels in } \\
\text { dredged material are no } \\
\text { concern and are unlikely to } \\
\text { influence decision }\end{array}$ & $\begin{array}{l}\text { Dredged material unsuitable } \\
\text { for sea disposal and disposed } \\
\text { of by other routes e.g. } \\
\text { landfill }\end{array}$ & - & - & - \\
\hline
\end{tabular}


The results that were obtained using the Microtox ${ }^{\circledR}$ assay were in agreement with the metal analysis; at reference site (C), the site with the lowest metal values, no toxicity was detected. Considering the results that were obtained with the Microtox ${ }^{\circledR}$ assay and the levels of metals, PAHs and PCBs that were considered acceptable in the surveyed sediments, the toxicity recorded in this bioassay was higher than expected. The low percentage values of the sediment samples caused $50 \%$ inhibition in $V$. fisheri luminescence (EC50 $15 \mathrm{~min}$ ). Therefore, individual metal, PCB or $\mathrm{PAH}$ concentrations alone do not explain the toxicity levels that were observed in the Microtox ${ }^{\circledR}$ bioassay. The chemical composition alone does not provide sufficient information on the bioavailability, mobility and toxicity of contaminants or on their potential harmful effects on the environment because different chemicals can interact and promote synergistic effects (Alvarenga et al., 2007; Rosa et al., 2007). In fact, PCB and most PAH data had values below the limit of detection, which reinforces the fact that chemical absence does not correspond to a lack of toxicity. Nonetheless, chemical analyses are important in identifying, quantifying and characterizing the composition of different samples (Girotti et al., 2008). Previous studies in the Ria de Aveiro have reported the presence of endocrine-disrupting chemicals (Jonkers et al., 2010; Sousa et al., 2010), with levels above those established by the European WFD (Council Directive 2000/60/EC), and organotin compounds, which are known to be responsible for imposex and female sterility (Barroso et al., 2002; Sousa et al., 2007). Sousa et al. (2007) detected various sites that exhibited levels exceeding the predicted no-effect concentration for tributyltin in water samples, and high levels of tributyltin were also recorded in sediment samples.

Sediment elutriates are essential for assessing the effects of dredging actions and the resuspension of metals and other toxic chemicals on water quality (Simpson et al., 2005). They are an important tool for understanding the potential bioavailability of contaminants because their presence in sediment pore water plays a crucial role in the overall toxicity of sediments (McCready et al., 2004). The reference site for our study area (C) had the lowest metal content in the elutriate analysis (as already recorded in the sediment analysis). This sampling site also had the lowest mortality percentage in the marine rotifer $B$. plicatilis bioassay. The results obtained for this site were significantly lower than those for sampling sites A and D. This result confirms that sampling site $C$ is a suitable reference site, and the higher toxicity of sampling sites A and D, though their individual metal, $\mathrm{PAH}$ and PCB concentrations were below the maximum permissible concentrations. This higher toxicity at sites $\mathrm{A}$ and $\mathrm{D}$ may be promoted by synergistic effects that occur among metals, PAHs and PCBs.

With the goal of improving surficial and ground water quality around Europe, the WFD was implemented in 2000. Nonetheless, several gaps can still be found in the current directive, such as the influence of sediment contamination in water quality assessment, an issue that is nearly overlooked and whose importance is not properly highlighted. Sediment quality is briefly mentioned throughout the directive: article 2 contains the definition 'environmental quality standard means the concentration of a particular pollutant or group of pollutants in water, sediment or biota which should not be exceeded in order to protect human health and the environment'; article 16 mentions strategies to avoid polluting water, "The Commission shall submit proposals for quality standards applicable to the concentrations of the priority substances in surface water, sediments or biota"; and in annex V, where, in point 1.2.6, it is stated that "standards may be set for water, sediment and biota". Additionally, ecotoxicological bioassays, such as acute and chronic tests, are only specified for water body types and aquatic taxa in annex $\mathrm{V}$, with no reference to sediment bioassays. In other words, the contaminants that are present in sediments can be identified through chemical analysis, but their effects are not properly determined.

\section{Conclusions}

The use of bioassays and sediment analysis to evaluate sediment quality is significant for assessing water quality, confirming the urgent need to correct current gaps $n$ the WFD on water quality analysis. Bioassays and biomonitoring are two key tools for evaluating the chemical and ecological states of water, sediment and biota in port areas. Both bioassays that were performed in this study were found to be accurate, reinforcing the significance of including these tools in water quality analysis, as already highlighted by the recommendations in French and Spanish legislation. Portuguese legislation still overlooks the ecotoxicological characterization of dredged materials, which is crucial for sediment disposal. Overall, it is urgent that ecotoxicological sediment analyses are recommended within the WFD and that EU member states adopt a standardized classification system for materials/sediments according to their degree of chemical contamination.

\section{Acknowledgements}

The present study was financed by the Atlantic Area Operational Programme, through the European Regional Development Fund (ERDF), Project PORTONOVO (ref 2009-1/119). We would also like to thank the administration of the Port of Aveiro and specifically Eng. Maria Manuel Cruz. The authors also thank the anonymous reviewers for their constructive criticism on a previous version of this manuscript.

\section{Appendix A. Supplementary material}

Supplementary data associated with this article can be found, in the online version, at http://dx.doi.org/10.1016/j.marpolbul.2013. 04.003 .

\section{References}

Adamo, P., Arienzo, M., Imperato, M., Naimo, D., Nardi, G., Stanzione, D., 2005. Distribution and partition of heavy metals in surface and sub-surface sediments of Naples city port. Chemosphere 61, 800-809.

Alagarsamy, R., 2006. Distribution and seasonal variation of trace metals in surface sediments of the Mandovi estuary, west coast of India. Estuar. Coast. Shelf Sci. 67, 333-339.

Alvarenga, P., Palma, P., Gonçalves, A.P., Fernandes, R.M., Cunha-Queda, A.C., Duarte, E., Vallini, G., 2007. Evaluation of chemical and ecotoxicological characteristics of biodegradable organic residues for application to agricultural land. Environ. Int. 33, 505-513.

Alzieu, C., Quiniou, F., 2002. GEODRISK: Software for the Assessment of Risks Linked to the Immersion of Dredging Sludge. Acte de colloque CEDA Dredging Days, Casa-blanca, pp. 22-24.

Arrêté du, 14/06/00. Relative to Baseline Levels to Consider in an Analysis of Marine or Estuarine Sediment Present in the Wild or Port (Arrêté du 14/06/00 relatif aux niveaux de référence à prendre en compte lors d'une analyse de sédiments marins ou estuariens présents en milieu naturel ou portuaire (JO n 184 du 10 août 200)).

Azur, 1998. Basic Solid-Phase Test. Azur Environmental, Carlsbad, CA, USA, p. 16.

Bailey, D., Solomon, G., 2004. Pollution prevention at ports: clearing the air. Environ. Impact Assess. Rev. 24, 749-774.

Barroso, C.M., Moreira, M.H., Bebianno, M.J., 2002. Imposex, female sterility and organotin contamination of the prosobranch Nassarius reticulatus from the Portuguese coast. Mar. Ecol. Prog. Ser. 230, 127-135.

Birch, G., Taylor, S., 1999. Source of heavy metals in sediments of the Port Jackson estuary, Australia. Sci. Total Environ. 227, 123-138.

Boonyatumanond, R., Wattayakorn, G., Togo, A., Takada, H., 2006. Distribution and origins of polycyclic aromatic hydrocarbons (PAHs) in riverine, estuarine, and marine sediments in Thailand. Mar. Pollut. Bull. 52, 942-956.

Borja, A., Elliott, M., 2007. What does 'good ecological potential' mean, within the European Water Framework Directive? Mar. Pollut. Bull. 54, 1559-1564.

Borja, Á., Galparsoro, I., Solaun, O., Muxika, I., Tello, E.M., Uriarte, A., Valencia, V., 2006. The European Water Framework Directive and the DPSIR, a 
methodological approach to assess the risk of failing to achieve good ecological status. Estuar. Coast. Shelf Sci. 66, 84-96.

BS, 1995. Soil Quality-Chemical methods-Determination of Organic and Total Carbon after Dry Combustion (elementary analysis) BS 7755-3.8. BS - British Standards.

CEDEX, 1994. Recommendations for the Management of Dredged Material in Spanish Ports. Ministry of Public Works, Transport and Environment (Recomendaciones para la gestión del material dragado en los puertos Españoles. Ministério de Obras Públicas, Transportes y Medio Ambiente), Madrid, p. 45

Chen, C.-W., Kao, C.-M., Chen, C.-F., Dong, C.-D., 2007. Distribution and accumulation of heavy metals in the sediments of Kaohsiung Harbor, Taiwan. Chemosphere 66, 1431-1440.

Costa, F.O., Correia, A.D., Costa, M.H., 1998. Acute marine sediment toxicity: a potential new test with the amphipod Gammarus locusta. Ecotoxicol. Environ. Saf. 40, 81-87.

Darbra, R.M., Pittam, N., Royston, K.A., Darbra, J.P., Journee, H., 2009. Survey on environmental monitoring requirements of European ports. J. Environ. Manage. 90, 1396-1403.

DelValls, T.Á., Forja, J.M., González-Mazo, E., Gómez-Parra, A., Blasco, J., 1998. Determining contamination sources in marine sediments using multivariate analysis. TrAC, Trends Anal. Chem. 17, 181-192.

Diário da República, 2007. Portaria n`1450/2007 de 12 de Novembro de 2007. Diário da República n`217/07 - I Série. Ministério do Ambiente, do Ordenamento do Território e do Desenvolvimento Regional. Lisboa, Portugal.

DIN, 1993. German Standard Methods for the Examination of Water, Waste Water and Sludge; Substance Group Analysis (group F); Determination of Lowvolatility Halogenated Hydrocarbons by Gas Chromatography (F 2) - Part 2. DIN 38 407-part 2. Din-Deutsche Einheitsver Institut, Berlin.

European Community, 2000. Water Framework Directive 2000/60/EC, Council Directive and European Parliament of 23 of October 2000. Establishing a framework for Community action in the field of water policy.

Fang, M.-D., Lee, C.-L., Yu, C.-S., 2003. Distribution and source recognition of polycyclic aromatic hydrocarbons in the sediments of Hsin-ta Harbour and adjacent coastal areas, Taiwan. Mar. Pollut. Bull. 46, 941-953.

Fatoki, O.S., Mathabatha, S., 2001. An assessment of heavy metal pollution in the East London and Port Elizabeth harbours. Water Sa 27, 233-240.

Girotti, S., Ferri, E.N., Fumo, M.G., Maiolini, E., 2008. Monitoring of environmental pollutants by bioluminescent bacteria. Anal. Chim. Acta 608, 2-29.

Goulielmos, A.M., 2000. European policy on port environmental protection. Global Nest: The Int. J 2, 189-197, <http://www.portodeaveiro.pt> (Port of Aveiro).

Huang, K.-M., Lin, S., 2003. Consequences and implication of heavy metal spatial variations in sediments of the Keelung River drainage basin, Taiwan. Chemosphere 53, 1113-1121.

ISO, 1995. ISO 10694: Soil Quality-Determination of Organic and Total Carbon after Dry Combustion (Elementary Analysis). ISO-The Internationals Organization for Standardization, Genève.

ISO, 1998. CSN EN ISO 6468 (757580): Water Quality - Determination of Certain Organochlorine Insecticides, Polychlorinated Biphenyls and Chlorobenzenes Gas Chromatographic Method after Liquid-liquid Extraction. ISO - The International Organization for Standardization, Genève.

ISO, 2005. ISO 17294: Water Quality - Application of Inductively Coupled Plasma Mass Spectrometry (ICP-MS). ISO-The Internationals Organization for Standardization, Genève.

ISO, 2007. ISO 11885: Water Quality-Determination of Selected Elements by Inductively Coupled Plasma Optical Emission Spectrometry (ICP-OES). ISO-The Internationals Organization for Standardization, Genève.

Jones, M.-A., Stauber, J., Apte, S., Simpson, S., Vicente-Beckett, V., Johnson, R., Duivenvoorden, L., 2005. A risk assessment approach to contaminants in Port Curtis, Queensland, Australia. Mar. Pollut. Bull. 51, 448-458.

Jonkers, N., Sousa, A., Galante-Oliveira, S., Barroso, C., Kohler, H.-P., Giger, W., 2010 Occurrence and sources of selected phenolic endocrine disruptors in Ria de Aveiro, Portugal. Environ. Sci. Pollut. Res. 17, 834-843.

Liß, W., Ahlf, W., 1997. Evidence from whole-sediment, porewater, and elutriate testing in toxicity assessment of contaminated sediments. Ecotoxicol. Environ. Saf. 36, 140-147.

Liu, W.X., Li, X.D., Shen, Z.G., Wang, D.C., Wai, O.W.H., Li, Y.S., 2003. Multivariate statistical study of heavy metal enrichment in sediments of the Pearl River Estuary. Environ. Pollut. 121, 377-388.

Loureiro, S., Ferreira, A.L.G., Soares, A.M.V.M., Nogueira, A.J.A., 2005. Evaluation of the toxicity of two soils from Jales Mine (Portugal) using aquatic bioassays. Chemosphere 61, 168-177.
McCready, S., Spyrakis, G., Greely, C.R., Birch, G.F., Long, E.R., 2004. Toxicity of surficial sediments from Sydney harbour and vicinity, Australia. Environ. Monit. Assess. 96, 53-83.

Morillo, J., Usero, J., Gracia, I., 2004. Heavy metal distribution in marine sediments from the southwest coast of Spain. Chemosphere 55, 431-442.

Narracci, M., Cavallo, R., Acquaviva, M., Prato, E., Biandolino, F., 2009. A test battery approach for ecotoxicological characterization of Mar Piccolo sediments in Taranto (Ionian Sea, Southern Italy). Environ. Monit. Assess. 148, 307-314.

Nendza, M., 2002. Inventory of marine biotest methods for the evaluation of dredged material and sediments. Chemosphere 48, 865-883.

OSPAR, 2004. Overview of Contracting Parties' National Action Levels for Dredged Material. Biodiversity Series, 22.

Peris-Mora, E., Orejas, J.M.D., Subirats, A., Ibáñez, S., Alvarez, P., 2005. Development of a system of indicators for sustainable port management. Mar. Pollut. Bull. 50, 1649-1660.

Quintino, V., Picado, A.M., Rodrigues, A.M., Mendonça, E., Costa, M.H., Costa, M.B., Lindgaard-Jørgensen, P., Pearson, T.H., 1995. Sediment chemistry-Infaunal community structure in a southern European estuary related to solid-phase Microtox $^{\circledR}$; toxicity testing. Aquat. Ecol. 29, 427-436.

Riba, I., Casado-Martínez, C., Forja, J.M., Valls, Á.D., 2004. Sediment quality in the Atlantic coast of Spain. Environ. Toxicol. Chem. 23, 271-282.

Rosa, E.V.C., Giuradelli, T.M., Corrêa, A.X.R., Rörig, L.R., Schwingel, P.R., Resgalla Jr. C., Radetski, C.M., 2007. Ecotoxicological evaluation of the short term effects of fresh and stabilized textile sludges before application in forest soil restoration. Environ. Pollut. 146, 463-469.

Simpson, S.L., Batley, G.E., Charriton, A.A., Stauber, J.L., King, C.K., Champan, J.C., Hyne, R.V., Gale, S.A., Roach, A.C., Maher, W.A., 2005. Handbook for Sediment Quality Assessment. Bangor, NSW.

Soclo, H.H., Garrigues, P., Ewald, M., 2000. Origin of Polycyclic Aromatic Hydrocarbons (PAHs) in Coastal Marine Sediments: Case Studies in Cotonou (Benin) and Aquitaine (France) Areas. Mar. Pollut. Bull. 40, 387-396.

Sousa, A., Matsudaira, C., Takahashi, S., Tanabe, S., Barroso, C., 2007. Integrative assessment of organotin contamination in a southern European estuarine system (Ria de Aveiro, NW Portugal): tracking temporal trends in order to evaluate the effectiveness of the EU ban. Mar. Pollut. Bull. 54, 16451653.

Sousa, A., Schönenberger, R., Jonkers, N., Suter, M., Tanabe, S., Barroso, C., 2010 Chemical and biological characterization of estrogenicity in effluents from WWTPs in Ria de Aveiro (NW Portugal). Arch. Environ. Contam. Toxicol. 58, $1-8$

Sprovieri, M., Feo, M.L., Prevedello, L., Manta, D.S., Sammartino, S., Tamburrino, S. Marsella, E., 2007. Heavy metals, polycyclic aromatic hydrocarbons and polychlorinated biphenyls in surface sediments of the Naples harbour (southern Italy). Chemosphere 67, 998-1009.

USEPA, 1996a. Method 8082: Polychlorinated Biphenyls (PCBs) by Gas Chromatography. USEPA-United States Environmental Protection Agency, Washington, DC.

USEPA, 1996b. Method 8091: Nitroaromatics and Cyclic Ketones by Gas Chromatography. USEPA-United States Environmental Protection Agency, Washington, DC

USEPA, 1996c. Method 8131: Aniline and Selected Derivatives by Gas Chromatography. USEPA-United States Environmental Protection Agency, Washington, DC.

USEPA, 1996d. Method 8270-C: Semi-volatile Organic Compounds by Gas Chromatography/Mass Spectrometry. US EPA-United States Environmental Protection Agency, Washington, DC

Valdés, J., Vargas, G., Sifeddine, A., Ortlieb, L., Guiñez, M., 2005. Distribution and enrichment evaluation of heavy metals in Mejillones Bay $\left(23^{\circ} \mathrm{S}\right)$, Northern Chile: geochemical and statistical approach. Mar. Pollut. Bull. 50 1558-1568.

Woodhead, R.J., Law, R.J., Matthiessen, P., 1999. Polycyclic aromatic hydrocarbons in surface sediments around England and Wales, and their possible biological significance. Mar. Pollut. Bull. 38, 773-790.

Zar, J.H., 1996. Biostatistical Analysis. Prentice-Hall International, Inc., New Jersey.

Zhang, L., Ye, X., Feng, H., Jing, Y., Ouyang, T., Yu, X., Liang, R., Gao, C., Chen, W., 2007. Heavy metal contamination in western Xiamen Bay sediments and its vicinity China. Mar. Pollut. Bull. 54, 974-982.

Zhou, H.-y., Peng, X.-t., Pan, J.-m., 2004. Distribution, source and enrichment of some chemical elements in sediments of the Pearl River Estuary, China. Cont. Shelf Res. 24, 1857-1875. 